Forthcoming in The Edward Elgar Research Handbook on Human Rights and Business, Surya Deva and David Birchall (eds.) - draft, please do not cite without permission.

\title{
The Role of Civil Society and Human Rights Defenders in Corporate Accountability
}

\section{Introduction}

Civil society plays an increasingly important role in corporate accountability. Governments and the international legal regime as currently constituted are unable to meet some of our most pressing societal challenges, ${ }^{1}$ while corporate power, influence and authority continues to grow. ${ }^{2}$ Barriers emerge, inter alia, from the territorially-bounded jurisdictions of states, ${ }^{3}$ the difficulty in creating treaty law, ${ }^{4}$ the statist nature of obligations under human rights law, ${ }^{5}$ and the nature of transnationally networked global capitalism today. ${ }^{6}$ John Ruggie describes an emergent business and human rights (BHR) tripartite governance order composed of the domestic and international legal regime, corporate governance, and 'a civil governance system involving stakeholders affected by business enterprises and employing various social compliance mechanisms." Jochnick and Bickford similarly describe civil society organizations (CSOs) as the 'third pillar... alongside the public and private sector'. ${ }^{8}$

CSOs emerge as key actors within this new paradigm: they can be more responsive, flexible, focused and better networked than state machineries. ${ }^{9}$ Civil society has adopted a wide array of tactics, from quasi-legalistic regulation to internet-enabled flash mob style campaigning, while also holding corporations to account through collaboration, lobbying, investigating, benchmarking, protest, legal assistance, and much more. Civil society is defined 'as the socio-sphere located between the family, the state, and the market and operating beyond the natural confines of national societies, polities and economies' ${ }^{10} \mathrm{CSO}$ are organizations emerging from civil society. The UN Guiding Principles on Business and Human Rights (UNGPs) reporting framework defines CSOs as '[n]on-State, not-for-profit, voluntary entities formed by people in the social sphere that are separate from the State and the market. CSOs

\footnotetext{
${ }^{1}$ Larry Catá Backer, 'Polycentric Governance in the Transnational Sphere: Private Governance, Soft Law, and the Construction of Public-Private Regulatory Networks for States and Transnational Corporations.' (2011) 17.1 Indiana Journal of Global Legal Studies 101; Kenneth Abbott and Duncan Snidal, 'Strengthening International Regulation Through Transnational New Governance: Overcoming the Orchestration Deficit,' (2009) 42 Vanderbilt Journal of Transnational Law 501; cf. on the legal construction of this system: Penelope Simons, 'International law's invisible hand and the future of corporate accountability for violations of human rights' (2012) Journal of Human Rights and the Environment ; David Kennedy. 'Law and the Political Economy of the World.' (2013) 26.1 Leiden Journal of International Law, 7.

${ }^{2}$ Florian Wettstein, Multinational corporations and global justice: human rights obligations of a quasigovernmental institution (Stanford 2009) (Wettstein, Global Justice).

${ }^{3}$ Stephen J. Kobrin, 'Private political authority and public responsibility: Transnational politics, transnational firms, and human rights' (2009) 19.03 Business Ethics Quarterly 349.

${ }^{4}$ Joost Pauwelyn, Ramses A. Wessel, and Jan Wouters, 'When structures become shackles: stagnation and dynamics in international lawmaking' (2014) 25.3 European journal of international law 733.

${ }^{5}$ Manisuli Ssenyonjo, 'Non-state Actors and Economic, Social and Cultural Rights', in Mashood A. Baderin, and Robert McCorquodale, eds. Economic, social and cultural rights in action. (OUP 2007) 109

${ }^{6}$ Leslie Sklair, Transnational capitalist class (John Wiley \& Sons Ltd 2012).

7 John Ruggie, 'Global governance and 'new governance theory': Lessons from business and human rights.' (2014) 20.1 Global Governance 5, 9.

${ }^{8}$ Chris Jochnick and Louis Bickford, 'The role of civil society in business and human rights', in Dorothée Baumann-Pauly and Justine Nolan. Business and Human Rights: From Principles to Practice. Routledge (2016) 182 (Jochnick and Bickford, Civil Society).

${ }^{9}$ Lester M. Salamon, 'Putting the civil society sector on the economic map of the world.' (2010) 81.2 Annals of Public and Cooperative Economics 167.

${ }^{10}$ Helmut Anheier and Nuno Themudo, 'Organisational forms of global civil society: implications of going global', in Marlies Glasius et al. eds, Global Civil Society. (OUP 2006) 191, 193.
} 
Forthcoming in The Edward Elgar Research Handbook on Human Rights and Business, Surya Deva and David Birchall (eds.) - draft, please do not cite without permission.

represent a wide range of interests and ties. They can include community-based organizations as well as non-governmental organizations (NGOs). ${ }^{11}$ As such CSOs display extreme diversity in terms of formality and institutionalization; size; the scope of their activities; their normative goals; and mode of operation. ${ }^{12}$ There is also very often overlap and many organizations are initiated jointly by civil society, business, and/or government agencies. For this reason it is not always easy to delineate a CSO from other types of organization. Many organizations begin as grassroots CSOs, but over time develop close links with governments or international institutions, thus blurring the lines. In this chapter I will adopt a broad definition of CSOs as any organization featuring significant input from civil society, including workers.

The United Nations Special Rapporteur (UNSR) on Human Rights Defenders (HRDs) defines HRDs as 'individuals and groups who, in their personal or professional capacity and in a peaceful manner, strive to protect and promote human rights. ${ }^{13}$ HRDs operate as the front-line of civil society, often within dangerous environments, and sometimes threatened by powerful interests. Perhaps the best evidence of their importance is seen in the seriousness and volume of these threats. The UNSR writes that the 'scale of killings [of HRDs] indicates a truly global crisis'. ${ }^{14}$ There 'were over 400 cases of attacks against human rights defenders that were confronting specific companies or sectors in 2015 and 2016... On average, three environmental activists were murdered each week in 2015. ${ }^{15}$ High profile killings include that of Berta Cáceres, a prominent land rights activist in Honduras, and Sikhosiphi Rhadebe, campaigning against a new titanium mine in South Africa, both in March 2016. ${ }^{16}$ Protecting HRDs has therefore become a crucial part of the BHR landscape.

Finally, corporate accountability is an umbrella term capturing both legal accountability (liability) and the plethora of softer and pressure forms of accountability. 'It encompasses the idea that those accountable should be answerable for the consequences of their actions and refers to 'non-legal risks of loss of reputation, denial of access to foreign markets, and shareholder dissent (not to mention plunging stock values)'. ${ }^{17}$ Waddock presents a list of foundational principles to which corporations should be held to account, ${ }^{18}$ and highlights the range of tactics that can be used to promote compliance with these principles. 'Social activism', including research, private regulation and investor strategies all contribute toward accountability. ${ }^{19}$

\footnotetext{
${ }^{11}$ UNGP Reporting, 'CSOs', at: https://www.ungpreporting.org/glossary/civil-society-organizations-csos/ [last accessed 14 January 2019].

${ }^{12}$ Rob Gray, Jan Bebbington, and David Collison, 'NGOs, civil society and accountability: making the people accountable to capital' (2006) 19.3 Accounting, Auditing \& Accountability Journal 319, 323.

${ }^{13}$ Human Rights Council. 'Situation of human rights defenders' UN Doc A/HRC/71/281 para. 26 (A/HRC/71/281)

14 ibid para. 7.

15 ibid para. 1.

16 ibid para. 1.

${ }^{17}$ Nadia Bernaz, 'Enhancing corporate accountability for human rights violations: is extraterritoriality the magic potion?' (2013) 117.3 Journal of Business Ethics 493. See also Nadia Bernaz, Business and Human Rights: History, Law and Policy-Bridging the Accountability Gap (Routledge 2016).

${ }^{18}$ Sandra Waddock, 'Creating corporate accountability: Foundational principles to make corporate citizenship real.' (2004) 50.4 Journal of Business Ethics 313, 319.

19 ibid 313.
} 
Forthcoming in The Edward Elgar Research Handbook on Human Rights and Business, Surya Deva and David Birchall (eds.) - draft, please do not cite without permission.

This chapter first defines the key terms, and then briefly summarizes the evolution of civil society's relationship with BHR. Next it turns to the various forms of civil society activism, divided into insider roles within governance institutions and firms, and outsider advocacy roles. It then discusses HRDs and some of the particular issues they face. Finally the chapter discusses rationales as to why businesses should seek to protect civil society, and concludes.

\section{The Evolution of Civil Society's Role in Business-Related Human Rights Accountability}

The intersection of business and human rights has taken some time to coalesce into a coherent activist arena. Human rights were held against the state, were violated by the state, and were protest vocabularies against the illegitimate use of state power ${ }^{20}$ Critics of corporations throughout the $20^{\text {th }}$ century were more likely to use Marxist, anarchist and other anti-capitalist vocabularies, ${ }^{21}$ and had little use, or even respect, for human rights. ${ }^{22}$ Critics of globalization coalesced around the World Trade Organization (WTO), and in 1999 'The Battle of Seattle', highlighted the size of the movement. ${ }^{23}$ In this campaign and others against corporations and financial interests, 'the mainstream human rights movement was largely absent' ${ }^{24}$ Thus, civil society largely saw the two arenas as separate, and requiring separate vocabularies.

The rise of economic, social and cultural rights as a civil society discourse, ${ }^{25}$ of global labour rights and the right to development, ${ }^{26}$ land rights, environmental rights and others, ${ }^{27}$ provided a bridge between corporate critiques and human rights. As globalization gathered pace, it became increasingly clear that the human rights movement could not ignore violations by corporations, and critics of corporations could adopt normatively forceful human rights vocabularies. ${ }^{28}$ The business and human rights movement grew out of this framework, ${ }^{29}$ with human rights experts drawn in by some major cases, such as Bhopal, ${ }^{30}$ and the killing of Ken Saro-Wiwa in Nigeria, ${ }^{31}$ and the Nike sweatshop protests that led to the creation of the Fair

\footnotetext{
${ }^{20}$ See for an overview: Steven R. Ratner, 'Corporations and human rights: a theory of legal responsibility.' (2001) 111.3 The Yale Law Journal 443.

${ }^{21}$ Barbara Epstein, 'Anarchism and the anti-globalization movement.' (2001) 53.4 Monthly review 1.

${ }^{22}$ See on Marx's critique of human rights: Costas Douzinas, The end of human rights: critical thought at the turn of the century (Hart Publishing 2000) 158-165.

${ }^{23}$ Anita Ramasastry, 'Corporate social responsibility versus business and human rights: Bridging the gap between responsibility and accountability.' Journal of Human Rights 14.2 (2015) 237, 241 (Ramasastry, Corporate)

${ }^{24}$ Jochnick and Bickford, Civil Society, n. 8: 182

${ }^{25}$ See Chris Jochnick, 'Confronting the impunity of non-state actors: new fields for the promotion of human rights.’ Human Rights Quarterly 21.1 (1999): 56-79, 57.

${ }^{26}$ Philip Alston. 'Ships passing in the night: the current state of the human rights and development debate seen through the lens of the Millennium Development Goals.' Human rights quarterly 27.3 (2005): 755-829.

${ }^{27}$ Olivier De Schutter, 'The green rush: The global race for farmland and the rights of land users.' (2011) 52 Harvard International Law Journal 503.

${ }^{28}$ On the normative power of human rights language see Philip Alston, 'Making space for new human rights: The case of the right to development' (1988) 1 Harvard Human Rights Yearbook 3.

${ }^{29}$ Ramasastry, Corporate, n. 23

${ }^{30}$ Surya Deva, Regulating corporate human rights violations: humanizing business (Routledge 2012) 24-45.

${ }^{31}$ Richard Boele, Heike Fabig, and David Wheeler, 'Shell, Nigeria and the Ogoni. A study in unsustainable development: The story of Shell, Nigeria and the Ogoni people-environment, economy, relationships: conflict and prospects for resolution.' (2001) 9.2 Sustainable development 74.
} 
Forthcoming in The Edward Elgar Research Handbook on Human Rights and Business, Surya Deva and David Birchall (eds.) - draft, please do not cite without permission.

Labor Association. ${ }^{32}$ Civil society activism was, and continues to be, a driving force in promoting BHR norms at both corporate and governmental levels.

The diversity of CSOs makes it is difficult to speak in generalities. Nonetheless one important, though not universal, trend, is the gradual move away from 'naming and shaming' corporate wrongdoers. ${ }^{33}$ Naming and shaming typifies the outsider protest movement, focusing on identifying violations and creating public pressure against them. The most successful name and shame cases therefore often relate to large, public-facing brands. Examples include the Nike sweatshops scandal, the suicides at Apple supplier Foxconn, ${ }^{34}$ and the pressure on firms using the Rana Plaza factory complex ${ }^{35}$ when it collapsed. Despite the continued virtues of this approach, there are serious limitations. Less brand-oriented firms often fail to respond to such tactics. Complex networks of suppliers and subcontractors make it difficult to build knowledge of exactly what is involved in corporate production, and to impose normatively forceful responsibility for harm caused. ${ }^{36}$ It is also increasingly understood that some forms of harm are caused by weak procedures and a lack of knowledge at the firm-level. Therefore helping firms to build this knowledge, rather than merely condemning them, can be a more useful solution.

For this reason, 'knowing and showing', a constructivist concept underlying human rights due diligence under the UNGPs, has emerged as a less confrontational, more experiential form of accountability. ${ }^{37}$ Knowing and showing means that companies investigate their own impacts, with external, including civil society, assistance, internalize the problems, and become willing and able to moderate them. ${ }^{38}$ The corporation should understand how their actions contribute to human rights violations, and in so doing become a more willing global citizen. CSOs still play a vital role in knowing and showing, whether as researchers or providing best practice guidance, but it morphs from contestation to collaboration; from opposition to partnership.

Knowing and showing has its critics. Such tactics are implicitly rooted in a belief that corporations want to improve their performances and that corporations will take on human

\footnotetext{
${ }^{32}$ Aurat Van Heerden, 'The Fair Labor Association (FLA) - Improving Workers Rights in Global Supply Chains' in Dorothée Baumann-Pauly and Justine Nolan, Business and Human Rights: From Principles to Practice (Routledge 2016) 128

${ }^{33}$ Marcia Narine, 'Living in a Material World - From Naming and Shaming to Knowing and Showing' in Martin, Jena, and Karen E. Bravo' The Business and Human Rights Landscape: Moving Forward, Looking Back (CUP 2015) 219.

${ }^{34}$ Jenny Chan and Ngai Pun, 'Suicide as protest for the new generation of Chinese migrant workers: Foxconn, global capital, and the state' (2010) Asia-Pacific Journal: Japan Focus 1.

${ }^{35}$ Clean Clothes Campaign, 'Rana Plaza: Demands to brands' (2013).

${ }^{36}$ Sarah Labowitz and Dorothée Baumann-Pauly, 'Business as usual is not an option: Supply chains sourcing after Rana Plaza.' Stern Center for Business and Human Rights (2014); see generally: Richard Locke, The promise and limits of private power: Promoting labor standards in a global economy (CUP 2013).

${ }^{37}$ Human Rights Council, 'Guiding Principles on Business and Human Rights: Implementing the United Nations "Protect, Respect and Remedy" Framework: Report of the Special Representative of the SecretaryGeneral on the issue of Human Rights and Transnational Corporations and Other Business Enterprises', A/HRC/17/31 (21 March 2011) (Guiding Principles).

${ }^{38}$ UNHRC, 'Report of the Special Representative of the Secretary General on the Issue of Human Rights and Transnational Corporations and Other Business Enterprises, John Ruggie: Business and Human Rights: Further Steps toward the Operationalization of the 'Protect, Respect and Remedy' Framework' A/HRC/14/27 (9 April 2010) para. 80.
} 
Forthcoming in The Edward Elgar Research Handbook on Human Rights and Business, Surya Deva and David Birchall (eds.) - draft, please do not cite without permission.

rights concerns in good faith. Some argue that attempts such as these to 'moralize the market ${ }^{\prime 39}$ are likely to struggle. The internalization of human rights as part of corporate policy may transform 'the many negative social externalities of global production into a positive image of showing [improving] performance'. ${ }^{40}$ O'Kelly documents this trend, analysing 346 CSR documents to reveal common framings of human rights as business risks to be managed through metrics and other tools common in business. ${ }^{41}$ In so doing, human rights are reshaped, minimized, and sometimes lost altogether. Tracking instances of child labour within supply chains may be possible through this technique, but comprehensively respecting the right to just work may not. Rights are 'put to work on businesses behalf... and lose any 'radical potential'. ${ }^{42}$ Further, the internalization of human rights in corporate projects may lead to the emboldened neglect of the wider impacts of the project on society. ${ }^{43}$

The historical and tactical issues raised above imply some major debates for CSOs today: insider or outsider; neutrality or politics, to contest or collaborate. All CSOs engaged in corporate accountability share similar normative goals, yet there are serious disagreements about how best to achieve these aims, as well as the extent of natural complementarity between diverse approaches. The next section details the main approaches taken today by CSOs and HRDs.

\section{Civil Society and Human Rights Defenders}

\subsection{Within Governance}

\subsubsection{Regulators}

The transnational nature of many BHR problems limits the efficacy of the statist regulatory order and engenders the evolution of polycentric governance. ${ }^{44}$ The 'new world order involves the refracture of power and a more polymorphous and heterodox system of hopefully coherent systems of rules that bind, sometimes like law and sometimes not. ${ }^{, 45}$ Under the new governance model, regulation should be responsive, flexible, involving cooperation and public-private partnerships. ${ }^{46}$

Such conceptualizations naturally invite CSO participation, which, in most guises, can be assumed to hold comparative advantages in locally-specific knowledge and flexibility over

\footnotetext{
${ }^{39}$ Ronen Shamir, 'The age of responsibilization: On market-embedded morality' (2008) 37.1 Economy and society 1,3 .

${ }^{40}$ Christian Scheper, 'From naming and shaming to knowing and showing': human rights and the power of corporate practice.' (2015) 19.6 The International Journal of Human Rights 737, 748.

${ }^{41}$ Ciarán O'Kelly, 'Human Rights and the Grammar of Corporate Social Responsibility' (2019) Social \& Legal Studies 1.

42 ibid 17-18.

${ }^{43}$ Olivier De Schutter argues that this is blind-spot for human rights: Olivier De Schutter, 'Transnational Corporations as Instruments of Human Development' in Philip Alston and Mary Robinson (eds.) Human Rights and Development (OUP 2005) 403, 407.

${ }^{44}$ Ruggie, Governance $n 7$.

${ }^{45}$ Larry Catá Backer, 'A Lex Mercatoria for Corporate Social Responsibility Codes Without the State? A Critique of Legalization Within the State Under the Premises of Globalization' (2016) 17 Indiana Journal of Global and Legal Studies 115.

${ }^{46}$ Kenneth W. Abbott and Duncan Snidal, 'Taking responsive regulation transnational: Strategies for international organizations' (2013) 7.1 Regulation \& Governance 95; Kenneth W. Abbott, and Duncan Snidal, 'Hard and soft law in international governance' (2000) 54.03 International organization 421.
} 
Forthcoming in The Edward Elgar Research Handbook on Human Rights and Business, Surya Deva and David Birchall (eds.) - draft, please do not cite without permission.

more institutional governance forms. Nolan argues that the 'sharing of regulatory authority from states to non-state actors (may constitute) a regulatory renaissance. ${ }^{47}$ CSOs have taken a leading role in the regulation of many transnational industries, often through multistakeholder initiatives (MSIs). These refer to voluntary initiatives where a variety of actors drawn from civil society, business, unions and other stakeholder groups cooperate in the design of standards, which are applied to member firms. ${ }^{48}$ Baumann-Pauly et al. describe MSIs as 'a default response to business and human rights challenges' ${ }^{49}$

The FLA, which regulates workers' rights around the world, describes itself as 'collaborative effort of universities, civil society organizations and socially responsible companies. ${ }^{50}$ It is affiliated with various CSOs which have particular regional, industry, or human rights expertise. ${ }^{51}$ The Fair Wear Foundation (FWF) adopts a broadly similar model, describing itself as a 'non-profit organisation that works with brands, factories, trade unions, NGOs and sometimes governments to verify and improve workplace conditions for garment workers in 11 production countries in Asia, Europe and Africa. ${ }^{52}$ Both have drafted codes of conduct to which they seek compliance from companies. These codes cover labour and human rights, including minimum wages, maximum hours, and prohibitions on child and forced labour. ${ }^{53}$

These standards epitomise the new governance architecture. They move away the statecentric paradigm to target specific industries or issues, regionally or globally. The readymade garment industry is primarily regulated privately; ${ }^{54}$ and CSOs are connected to numerous global and local regulatory projects in mining; agricultural; fishing; transparency; digital technology and many more. ${ }^{55}$ The link is generally that the industry operates outside of (reliable) state regulation, either through complex chains of production, in insecure environments, or in cyberspace. In such situations, the knowledge and tenacity of CSOs is vital first in highlighting the problems, and eventually in taking on a regulatory role.

\footnotetext{
${ }^{47}$ Justine Nolan, 'Refining the rules of the game: The corporate responsibility to respect human rights' (2014) 30 Utrecht Journal of International and European Law 7, 8-9.

${ }^{48}$ Peter Utting, 'Rethinking Business Regulation: From Self-Control to Social Control' (Business and Society Programme Paper Number 15, September 2005)

<http://www.unrisd.org/unrisd/website/document.nsf/462fc27bd1fce00880256b4a0060d2af/f02ac3db0ed406e0c 12570a10029bec8/\$FILE/utting.pdf >

${ }^{49}$ Dorothée Baumann-Pauly et al. 'Setting and enforcing industry-specific standards for human rights: the role of multi-stakeholder initiatives in regulating corporate conduct' in Dorothée Baumann-Pauly and Justine Nolan (eds) Business and Human Rights: From Principles to Practice (Routledge 2016) 108.

${ }^{50}$ FLA, 'About Us', at: http://www.fairlabor.org/about-us [last accessed 14 January 2019].

${ }^{51}$ FLA, 'Affiliates', at: http://www.fairlabor.org/affiliates/civil-society-organizations [last accessed 14 January 2019].

${ }^{52}$ FWF, 'Approach', at: https://www.fairwear.org/about/approach/ [last accessed 14 January 2019].

${ }^{53}$ FLA, 'Labor Standards', at: http://www.fairlabor.org/our-work/labor-standards [last accessed 14 January 2019]; FWF, 'Labour Standards', at: https://www.fairwear.org/labour-standards/ [last accessed 14 January 2019].

${ }^{54}$ Niklas Egels-Zandén and Henrik Lindholm, 'Do codes of conduct improve worker rights in supply chains? A study of Fair Wear Foundation' (2015) 107 Journal of Cleaner Production 31 (Egels-Zandén and Lindholm, Rights).

55 See generally: Sébastien Mena and Guido Palazzo, 'Input and output legitimacy of multi-stakeholder initiatives' (2012) 22.03 Business Ethics Quarterly 527.
} 
Forthcoming in The Edward Elgar Research Handbook on Human Rights and Business, Surya Deva and David Birchall (eds.) - draft, please do not cite without permission.

Some private regulators are heavily-critiqued as little more than greenwashing initiatives run by industry ${ }^{56}$ and concerns are often raised about CSOs becoming too cosy with corporate members,${ }^{57}$ and ineffective ${ }^{58}$ Deeper critiques relate to the extent to which they encourage the abrogation of government responsibility, ${ }^{59}$ and the dislocation that metrics can engender from the real needs of rights holders. ${ }^{60}$ Despite these critiques, MSIs are continuing to evolve and spread, and provide a vital, if imperfect, tool, in transnational regulation today.

\subsubsection{Benchmarking}

Benchmarking refers to the setting of standards and metrics by which to evaluate the human rights performance of firms. A selected group of corporations are then evaluated according to these standards, to provide a comparative benchmark to inform stakeholders. The result is a sectoral dataset of human rights standards. The Corporate Human Rights Benchmark (CHRB) is the first specifically benchmarking initiative specifically covering BHR, but the practice has a long history through various environmental and sustainability projects, and in corporate practice. It is described as 'a unique collaboration led by investors and civil society organisations dedicated to creating the first open and public benchmark of corporate human rights performance' ${ }^{61}$ It seeks to tap into the 'competitive nature of the market' and create 'a race to the top' in standards. ${ }^{62}$ The Benchmark provides comparative statistics on policies, processes, and practices firms have in place to systematize their human rights approach and how they respond to serious allegations. It aims to eventually rank the top 500 globally-listed companies on their human rights-related policies. ${ }^{63}$

The CHRB produced its first results in 2017, in the apparel, agricultural and extractive sectors. In 2018 the methodology was revised and results were released in November of that year. There six overall 'Measurement Themes and Indicators'. These are 'Governance and Policy Commitments', which includes 'Policy Commitments' (accounting for 5\% of the total weighting) and 'Board Level Accountability' (also 5\%). Second is 'Embedding Respect and Human Rights Due Diligence', which includes 'Embedding Respect for Human Rights in Company Culture and Management Systems' (10\%) and 'Human Rights Due Diligence' (15\%). Third is 'Remedies and Grievance Mechanisms' (15\%) Fourth is 'Performance: Company Human Rights Practices' (20\%, with different standards for each industry sector) Fifth is 'Performance: Responses to Serious Allegations' (20\%). Sixth is 'Transparency'. ${ }^{64}$ $(10 \%)$. Focusing on apparel, specific benchmarks include: payment of a living wage to

\footnotetext{
${ }^{56}$ Niklas Egels-Zandén and Evelina Wahlqvist, 'Post-partnership strategies for defining corporate responsibility: The business social compliance initiative' (2007) 70.2 Journal of business ethics 175.

${ }^{57}$ Peter Fleming, John Roberts, and Christina Garsten, 'In search of corporate social responsibility: Introduction to special issue' (2013) 20.3 Organization 337, 339.

${ }^{58}$ Egels-Zandén and Lindholm, Rights, n 54.

${ }^{59}$ Joel Bakan, 'The Invisible Hand of Law: Private Regulation and the Rule of Law'(2015) 48 Cornell International Law Journal 279

${ }^{60}$ See $\mathrm{n} 40$ and 41.

${ }^{61}$ CHRB, 'Press Release 2017 Results' at: 〈https://www.corporatebenchmark.org/2017-results-press-release> [last accessed 14 January 2019].

62 ibid

${ }^{63}$ Casey O’Connor and Sarah Labowitz, 'Measuring Human Rights Performance for Investors' (2017).

${ }^{64} \mathrm{CHRB}$, 'Corporate human rights benchmark methodology 2018', (2018), https://www.corporatebenchmark.org/sites/default/files/documents/CHRB\%202018\%20Methodology\%20Web \%20Version.pdf 39-112.
} 
Forthcoming in The Edward Elgar Research Handbook on Human Rights and Business, Surya Deva and David Birchall (eds.) - draft, please do not cite without permission.

workers and supply chain workers; child and forced labour protections; debt bondage protections; union protections; health and safety; women's rights; working hours; purchasing policy and transparency objectives. ${ }^{65}$

The 2018 results covered 101 companies. Phil Bloomer, executive director of the Business \& Human Rights Resource Centre and member of the advisory council for the Corporate Human Rights Benchmark, wrote in announcing the results that ' $[\mathrm{t}]$ he great majority [of companies] have barely left the starting line, with 40 of the 101 companies surveyed failing to show any evidence of identifying or mitigating human rights issues in their supply chains. ${ }^{66}$ Nonetheless, some firms did show evidence of instigating the desired race to the top. Data showed that some firms scored consistently highly in most categories, and firms such as Adidas both scored highly and showed significant improvements on last year. ${ }^{67}$ The most problematic areas were human rights due diligence, payment of living wages, public policy commitments to human rights, and the prevalence of child labour in the agricultural and apparel sectors. ${ }^{68}$

It is too early to tell how much impact the CHRB will have. There are various established critiques of benchmarking, including that the metrics will fail to capture some policies, that policies may tick the box but be ineffective, and that over time corporations can game the system, particularly as much of CHRB is based on policy pronouncements rather than action. ${ }^{69}$ Nonetheless, engendering a race to the top through a competitive process has natural synergy with business practice. As intersubjective knowledge develops around the initiative it is possible that it could act successfully as both carrot and stick to firms and industries.

\subsubsection{Legal Assistance}

CSOs provide various forms of legal assistance. This is vital due to the complexity, specialist knowledge and financial requirements that such a case can entail. Despite the wealth of new tactics, legal accountability still provides the strongest remedies, the most tangible justice, ${ }^{70}$ and often helps to deliver the strongest moral condemnation. ${ }^{71}$ Some CSOs specialize in providing legal assistance, while more commonly public interest law firms will partner with local CSOs to develop cases. CSOs are highly visible as amicus curiae in many human rights cases. $^{72}$

\footnotetext{
65 ibid 87-94 [last accessed 14 January 2019].

${ }^{66}$ Phil Bloomer, 'New human rights ranking shows most firms have barely left the starting line' Ethical Corporation 11 November 2018, at http://ethicalcorp.com/new-human-rights-ranking-shows-most-firms-havebarely-left-starting-line [last accessed 14 January 2019].

${ }^{67}$ CHRB, 'Banding Table' (undated), https://www.corporatebenchmark.org/ [last accessed 14 January 2019].

${ }^{68}$ CHRB, 'Key Findings' (2018),

https://www.corporatebenchmark.org/sites/default/files/documents/CHRBKeyFindings2018.pdf 12-13[last accessed 14 January 2019].

${ }^{69}$ C\&E. '5 observations on the Corporate Human Rights Benchmark and its implications for big business', (undated),

<http://www.candeadvisory.com/news/5-observations-corporate-human-rights-benchmark-and-its-implicationsbig-business $>$ [last accessed 14 January 2019].

${ }^{70}$ Dinah Shelton, Remedies in international human rights law (OUP 2015).

${ }^{71}$ Judith Schrempf-Stirling and Florian Wettstein, 'Beyond Guilty Verdicts: Human Rights Litigation and its Impact on Corporations' Human Rights Policies.' (2015) Journal of Business Ethics 1.

72 Olivier De Schutter, International human rights law: cases, materials, commentary (CUP 2010) 37.
} 
Forthcoming in The Edward Elgar Research Handbook on Human Rights and Business, Surya Deva and David Birchall (eds.) - draft, please do not cite without permission.

EarthRights International assist in legal cases and provide information. The group has released a guide detailing how the US Foreign Legal Assistance Statute can be used 'to request information belonging to a U.S. person or company if the information will be helpful in a foreign or international legal proceeding. ${ }^{73}$ They are currently engaged in three cases using this statute. ${ }^{74}$ CSOs are increasingly using strategic lawsuits to seek accountability and remedy. These strengthen the position of marginalized groups as rights-holders, while also publicising the issue in the normatively strong terms of violations of human and labour rights law. The European Center for Constitutional and Human Rights (ECCHR) is an independent, non-profit legal and educational organization dedicated to protecting civil and human rights worldwide. It was founded in 2007 by a small group of human rights lawyers. ${ }^{75}$ The ECCHR helped initiate a legal action against the German clothing company Kik for a fire that occurred at a Pakistani supply chain factory that killed 258 people in $2012 .{ }^{76}$ On January 10 2019 , the court rejected the lawsuit on the grounds of a statutory limitation on tort claims under Pakistani law. ${ }^{77}$ Leigh Day is a public interest law firm that works with CSOs and HRDs around the world. They are currently representing 40,000 individuals across two communities in litigation against Shell over the damage caused by major oil spills in the Niger Delta. ${ }^{78}$ As detailed below, corporations are equally adept at using the legal system against CSOs and HRDs.

\subsubsection{Labour Movements}

For a long time, there was little connection between the international labour movement and the international human rights movement, despite many shared issues. ${ }^{79}$ Human rights were historically aimed solely at the state, and particularly challenging serious crimes by states against their own people. Labour movements also targeted the state, seeking greater regulation of businesses, but also built powerful unions through which to make extra-legal demands of employers. The demands of each movement, particularly in the developed world, were quite different. While there was always some overlap, particularly around issues such as child labour and slavery, the two movements had enough distinctions to be normatively divergent.

\footnotetext{
${ }^{73}$ EarthRights International. Using U.S. Courts to Obtain Information for Foreign Legal Cases foreign legal assistance actions under 28 u.s.c. $\$ 1782$

${ }^{74}$ EarthRights International. 'Foreign Legal Assistance', (undated) at:

<https://www.earthrights.org/legal/foreign-legal-assistance> [last accessed 14 January 2019].

${ }^{75}$ European Center for Constitutional and Human Rights. 'About', (undated) at:

<https://www.ecchr.eu/en/about.html> [last accessed 14 January 2019].

${ }^{76}$ European Center for Constitutional and Human Rights. 'Q\&A on the Compensation Claim against KiK', (undated), at:

<https://www.ecchr.eu/en/case/kik-paying-the-price-for-clothing-production-in-south-asia/> [last accessed 14 January 2019].

${ }^{77} \mathrm{https}$ ://www.ecchr.eu/nc/en/press-release/regional-court-in-dortmund-dismisses-pakistanis-complaint-againstkik/ [last accessed 14 January 2019].

${ }^{78}$ Leigh Day. '40,000 Nigerians take Shell to the UK High Court following oil spills'. 21 November 2016, at: <https://www.leighday.co.uk/News/News-2016/November-2016/40000-Nigerians-take-Shell-to-the-UK-HighCourt-f $>$ [last accessed 14 January 2019].

${ }^{79}$ Jochnick and Bickford, Civil Society, n 8, 185
} 
Forthcoming in The Edward Elgar Research Handbook on Human Rights and Business, Surya Deva and David Birchall (eds.) - draft, please do not cite without permission.

This changed with the global anti-sweatshop movement in the 1990s, when unions and human rights groups cooperated to challenge the working conditions in overseas factories of big brands. ${ }^{80}$ Most MSIs mentioned above, for example, use both ILO and human rights standards in their codes of conduct, while all support the right to freedom of association. ${ }^{81}$ Global unions such as IndustriALL and the International Trade Union Confederation (ITUC) have also begun talking in human rights language, as well as adopting certain human rights priorities. ${ }^{82}$ Today, the ITUC campaigns on child labour, migrant labour, domestic workers, and seeks to influence policy at IGOs. IndustriALL takes the more collaborative route, signing Global Framework Agreements (GFAs) with transnational corporations, whereby those firms adopt labour, human rights and environmental standards, across their global operations.

A number of fairly recent shifts facilitated convergence. First, economic globalization put brought issues of human rights and labour rights together in situations such as supply chain manufacturing. Corporations were simultaneously faced with allegations ranging from fatalities and serious injuries, to child labour and excessive working hours. Second, the increased attention upon socio-economic rights brought economic concerns more to the forefront of rights discourse. As such labour rights came to seen as indivisible from wider human rights concerns. Fair pay, for example, is often a necessary component of secure access to food and healthcare, and particularly in developing countries. Finally, the BHR movement has developed a more comprehensive rights outlook over time. The ILO declaration on fundamental principles and rights at work is included as part of the UNGPs. This covers:

(a) freedom of association and the effective recognition of the right to collective bargaining;

(b) the elimination of all forms of forced or compulsory labour;

(c) the effective abolition of child labour; and

(d) the elimination of discrimination in respect of employment and occupation.

Other rights, including those of indigenous peoples (see Chapter 18), environmental rights, and rights under international humanitarian law, are also widely seen as rights that business should respect.

\subsubsection{Collaboration with Corporations}

In 1999 Kofi Annan, in a speech to the World Economic Forum in Davos, signalled the thawing of relations between the UN and corporations. Calling to attention to the successes of the embedded liberalism era, ${ }^{83}$ and the threats unstable and anarchic global markets posed, he argued that until the global economy is made socially responsible it would remain:

\footnotetext{
80 ibid.

${ }^{81}$ Fair Wear Foundation. 'Code of Labour Practices' at: https://www.fairwear.org/wpcontent/uploads/2016/06/fwfcodeoflabourpractices.pdf [last accessed 14 January 2019].

${ }^{82}$ International Trade Union Confederation. 'The Global Refugee Crisis'. November 2015, at: $<$ https://www.ituc-csi.org/IMG/pdf/global_refugee_crisis.pdf $>$ [last accessed 14 January 2019].

83 John Ruggie, 'International regimes, transactions, and change: embedded liberalism in the postwar economic order.' (1982) 36.2 International organization 379.
} 
Forthcoming in The Edward Elgar Research Handbook on Human Rights and Business, Surya Deva and David Birchall (eds.) - draft, please do not cite without permission.

vulnerable to backlash from all the "isms" of our post-cold-war world: protectionism; populism; nationalism; ethnic chauvinism; fanaticism; and terrorism...Specifically, I call on you... to embrace, support and enact a set of core values in the areas of human rights, labour standards, and environmental practices. ${ }^{84}$

Since this speech, and subsequent creation of the UN Global Compact, there has been a marked shift in the collaborative efforts of CSOs to work with corporations. ${ }^{85}$ Save the Children 'believes that cooperation with companies that are 'worst in class' would be beneficial since it would have a great incentive to try to change them. ${ }^{, 86}$ As CSOs have professionalized and corporations have become more responsive to human rights concerns, there is an increase feeling that businesses can be willing partners, and moreover that partnership is essential to overcoming entrenched problems. Partnership may be undertaken at an informal or ad-hoc level, or at a more systemic level, or as part of regulatory projects, such as MSIs and certification schemes. Collaboration can be used to, inter alia, spread knowledge of current best practice; raise awareness of relevant human rights issues; engage in partnership projects; provide training and advisory services; raise rights-related standards, and to monitor such provisions. ${ }^{87}$

Nonetheless, such collaboration is often controversial. ${ }^{88}$ Allegations of CSOs helping to 'greenwash' corporate activities - meaning to give a veneer of respectability to harmful acts, remain common. Collaborative mechanisms sometimes favour corporate members and fail to hold them to account. ${ }^{89} \mathrm{~A}$ related issue emerges from what Vormedal has termed 'business and industry non-governmental organizations' (BINGOs). ${ }^{90}$ These are business-run organizations ranging (in environmental parlance) from 'grey', meaning hostile to regulation, to 'green' meaning pro-regulation and environmental improvements, often for reasons of business self-interest (such renewable energy firms). ${ }^{91}$ BINGOs are primarily a vehicle through which businesses can promote their own interests in a more legitimate way, including through research and information dissemination, and lobbying, though may often partner with CSOs. Common tactics include the presentation of data favourable to their interests, as well as partnering with more legitimate groups where there interests may align. Some BINGOs will adopt the stylized discourses of CSOs or impartial research organizations to gain legitimacy. ${ }^{92}$ Hayes and Oestreich use a broader schematic, delineating NGOs into 'brown',

\footnotetext{
${ }^{84}$ Kofi Annan, 'Secretary-General proposes global compact on human rights labour, environment, in address to World Economic Forum in Davos’ Press Release SG/SM/6881 1 February 1999, at: http://www.un.org/press/en/1999/19990201.sgsm6881.html [last accessed 14 January 2019].

${ }^{85}$ Peter Utting, 'Corporate responsibility and the movement of business.' (2005) 15.3 Development in practice 375 (Utting, Corporate).

${ }^{86}$ Jenny Ählström, and Emma Sjöström, 'CSOs and business partnerships: Strategies for interaction' (2005) 14.4 Business Strategy and the Environment 232 (Ählström and Sjöström, CSOs).

${ }^{87}$ Luc Zandvliet and Mary Anderson, Getting it right: making corporate-community relations work (Greenleaf 2009).

${ }^{88}$ Michael Yaziji and Jonathan Doh. NGOs and corporations: Conflict and collaboration. (CUP 2009).

${ }^{89}$ Surya Deva. 'Global Compact: A Critique of the UN's public-private partnership for promoting corporate citizenship' (2006) 34 Syracuse Journal of International Law and Commerce 107.

${ }^{90}$ Irja Vormedal, 'The influence of business and industry NGOs in the negotiation of the Kyoto mechanisms: the case of carbon capture and storage in the CDM' (2008) 8.4 Global Environmental Politics 36, 36.

91 ibid. 39-43, see especially table at 41.

92 ibid. 50-51.
} 
Forthcoming in The Edward Elgar Research Handbook on Human Rights and Business, Surya Deva and David Birchall (eds.) - draft, please do not cite without permission.

those that care 'considerably about the bottom line of firms and about the cause', and 'green' that focus more on social goals. ${ }^{93}$

\subsection{Outsider Roles}

3.2.1. As stakeholders in IGO standard-setting and national law

CSOs can influence national and international law and regulation most readily during stakeholder consultations, wherein they act as an organizational locus for generating carefully considered and normatively legitimate stakeholder viewpoints. Many have voiced concerns over the increasing role of corporations in government and inter-governmental organizations, and its impact on human rights discourse. ${ }^{94}$ These same processes have opened up space for CSOs to take a much more active role in rule-making, and stakeholder consultation is the norm for most IGO policies. ${ }^{95} \mathrm{CSO}$ offer an organized and legitimate platform for social needs to be elevated into institutional discussion.

Many CSOs offered submissions during the drafting of the UNGPs, including Amnesty International, ActionAid, and the Center for Human Rights \& Environment (CEDHA Argentina). ${ }^{96}$ The Treaty Alliance, composed of a multiplicity of CSO groups, is playing a key role in the negotiations and normative push in support of the binding business and human rights treaty. ${ }^{97}$ Involvement in law-making is seen both in their positive contributions to creating law, and their contestation of law. The Multilateral Agreement on Investment (MAI), which featured broad state and corporate support, was defeated after a 'coalition of more than 600 organizations in 70 countries sprang into 'virtual existence' on the World Wide Web almost overnight to oppose it. ${ }^{98}$ Shift, conversely, was created to 'put the Guiding Principles into practice'. ${ }^{99}$ At national level, the most progressive recent laws often have the fingerprints of civil society on them. The Transparency in Supply Chain provision of the UK Modern Slavery Act (Section 54), was pushed forward by activist group CORE; ${ }^{100}$ the Swiss Coalition of Corporate Justice (SCCJ) has drawn together 80 CSOs to push a mandatory due diligence law $^{101}$ similar to the French Act on the Duty of Care (see chapter 7).

\footnotetext{
${ }^{93}$ Anthony Heyes, and Andreas Marcel Oestreich. "A theory of social license when regulatory pressure is jointly produced by an EPA and an NGO." (2018) 54.3 Journal of Regulatory Economics 219.

${ }^{94}$ Upendra Baxi describes the emergence of 'market-friendly human rights'. Upendra Baxi, The future of human rights (OUP 2012) 258-261; 276-302.

${ }^{95}$ Steve Charnovitz. 'Nongovernmental organizations and international law' (2006) 100.2 The American Journal of International Law 348.

96 See list at: BHRRC. '2008 report by John Ruggie to Human Rights Council, and related materials' (undated), at:

<https://business-humanrights.org/en/un-secretary-generals-special-representative-on-business-humanrights/reports-to-un-human-rights-council/2008> [last accessed 14 January 2019].

97 Treaty Alliance, at: 〈http://treatymovement.com/> [last accessed 14 January 2019].

98 John Gerard Ruggie. 'Reconstituting the global public domain-issues, actors, and practices.' European journal of international relations 10.4 (2004): 499, 511.

${ }^{99}$ Shift. 'Our Story' (undated) at: 〈https://www.shiftproject.org/who-we-are/> [last accessed 14 January 2019 ].

${ }^{100}$ CORE. 'Modern Slavery Bill campaign' (undated), at: <http://corporate-responsibility.org/issues/modern-slavery-bill/msb-storify/> [last accessed 14 January 2019].

${ }^{101}$ Swiss Coalition of Corporate Justice. 'Online registry open for statements under UK Modern Slavery Act' 21 March 2016, at:

<http://corporatejustice.org/news/131-online-registry-open-for-statements-under-uk-modern-slavery-act> [last accessed 14 January 2019].
} 
Forthcoming in The Edward Elgar Research Handbook on Human Rights and Business, Surya Deva and David Birchall (eds.) - draft, please do not cite without permission.

\subsubsection{Shareholder Activism}

Second, shareholder activism uses the leverage that investors have over a firm's policies and priorities to demand coherence with human rights standards. The concept goes back to one of the first codes of conduct, the apartheid-era Sullivan Principles in South Africa, which set standards for doing business in the country, and advocated that institutional investors withdraw from corporations practicing apartheid policies. ${ }^{102}$ One more direct form sees CSOs or individuals buy shares in companies in order to speak with an authoritative voice when raising complaints and proposing changes to corporate policy. This is undertaken by groups such as Actares, EIRIS, Ethical Shareholders, and Social Investment Forum. ${ }^{103}$ There are natural financial limits to how influential such campaigns can be. Another form sees CSOs help to sway investors toward socially-responsible models, rather than use their own capital. Investors 'have the power to influence the way investment managers address human rights'. ${ }^{104}$ The Norwegian Investment Fund is the most famous example of a sociallyresponsible (and profitable) model, though is not without its critics. ${ }^{105}$ Another push is toward long-term investment strategies, argued to be both better for the firm, and stakeholders. ${ }^{106}$

Shareholder activism is a useful intra-systemic tool by which to influence large corporations. It has been shown to be a profitable model, and, if enough investors cohere to its principles, will almost inevitably promote social policies. However, it is not yet systematized, with 'a large degree of discretion' going into human rights investment analyses. ${ }^{107}$ The vast array of possible investment sources presents a challenge, as do questions such as how to determine the less ethical firms, and whether to invest in the more ethical firms in problematic industries such as fossil fuels. ${ }^{108}$

Two interrelated concerns arise from shareholder activism. First, even activist shareholders still want to make profit, and human rights demands cost money. Therefore shareholder activism may support minimalistic and superficial forms of human rights compliance. Second is the deeper concern around human rights activists joining forces with financiers. The wealth generated from the stock market goes primarily to a relatively small group of wealthy investors. This is therefore a significant cause of inequality in the world, and as such helps to undergird corporate and other forms of elite power. As multiple reports from Philip Alston, UNSR on extreme poverty and human rights, have noted, this inequality and elite power

\footnotetext{
${ }^{102}$ Christopher McCrudden, 'Human rights codes for transnational corporations: what can the Sullivan and MacBride principles tell us?' (1999) 19.2 Oxford Journal of Legal Studies 167.

${ }^{103}$ Utting, Corporate, n. 85.

${ }^{104}$ Institute of Human Rights and Business, Investing the Rights Way, (2013) <https://www.ihrb.org/pdf/Investing-the-Rights-Way/Investing-the-Rights-Way.pdf> [last accessed 14 January 2019].

${ }^{105}$ Mary Dowell-Jones, 'Investors: models and strategies for engaging with human rights' in Baumann-Pauly, Dorothée, and Justine Nolan. Business and Human Rights: From Principles to Practice (Routledge 2016) 219 106 ibid. at 225

107 ibid.at 222

108 Jeremy Moon and Xi Shen, 'CSR in China research: Salience, focus and nature' (2010) 94.4 Journal of Business Ethics 613; Larry Catá Backer, 'China’s Corporate Social Responsibility with National Characteristics' in Jena Martin and Karen E. Bravo. The Business and Human Rights Landscape: Moving Forward, Looking Back (CUP 2015) 530.
} 
Forthcoming in The Edward Elgar Research Handbook on Human Rights and Business, Surya Deva and David Birchall (eds.) - draft, please do not cite without permission.

often engenders serious human rights problems. ${ }^{109}$ If extreme inequality is a human rights issue, as Alston argues, ${ }^{110}$ ethical investment may be inherently contradictory.

\subsubsection{Watchdog Activism}

Watchdog activism involves naming and shaming, identifying and publicising corporate malpractice, and research into the darker corners of business activity. Numerous groups are to some extent engaged in watchdog activism, often alongside more collaborative engagements. Some, such as the Transnational Institute (TNI) make clear their anti-corporate, antineoliberal credentials, ${ }^{111}$ others are highly specific, such as International Baby Food Action Network (IBFAN), and some, such as SOMO (see below) are a research organization with a watchdog-orientation. Many groups work in specific sectors, such as land rights ${ }^{112}$ and the right to food. ${ }^{113}$

Watchdog activism is frequently undertaken by CSOs seeking radical change to the global economic system. The Association for the Taxation of financial Transactions and Aid to Citizens (ATTAC) 'fight for the regulation of financial markets, the closure of tax havens, the introduction of global taxes to finance global public goods, the cancellation of the debt of developing countries, fair trade, and the implementation of limits to free trade and capital flows. ${ }^{114}$ ATTAC has also, however, filed charges to the OECD contact point in Sweden against Swedish multinational corporations alleging violations of the OECD's Norms for Multinational Corporations. ${ }^{115}$ The Public Eye Awards were a counter-movement to the World Economic Forum meetings from 2005-2015, organized by The Berne Declaration, now renamed 'Public Eye'. ${ }^{116}$ They gave awards to companies with the very worst human rights and environmental records, and in 2015 awarded Chevron 'The Public Eye Lifetime Award for Corporate Irresponsibility Award.'117

With the move towards collaboration many organizations are adopting less hostile tones, and those that take explicitly anti-corporate positions may be considered less legitimate (see below). This has led to many losing their more overt political stances, and moving into demonstrative research.

\footnotetext{
${ }^{109}$ Report of the Special Rapporteur on extreme poverty and human rights on the enjoyment of civil and political rights by persons living in poverty, 10 October 2017, A/72/502; Statement on Visit to the USA, by Professor Philip Alston, United Nations Special Rapporteur on extreme poverty and human rights, 15 December 2017, https://www.ohchr.org/EN/NewsEvents/Pages/DisplayNews.aspx?NewsID=22533\&LangID=E [last accessed 14 January 2019].

${ }^{110}$ Report of the Special Rapporteur on extreme poverty and human rights, Philip Alston, on extreme inequality and human rights, A/HRC/29/31, 27 May 2015.

${ }^{111}$ Among the agendas therein are to 'dismantle corporate power'. See: Transnational Institute. 'Mission' (undated) at: 〈https://www.tni.org/en/page/mission> [last accessed 14 January 2019].

112 E.g. Landesa, at: <https://www.landesa.org/> [last accessed 14 January 2019].

${ }^{113}$ E.g. La Via Campesina, at: 〈https://viacampesina.org/en/index.php/main-issues-mainmenu-27> [last accessed 14 January 2019].

${ }^{114}$ Association for the Taxation of financial Transactions and Aid to Citizens. 'Overview' (undated) at: $<$ https://www.attac.org/en/overview> [last accessed 14 January 2019].

115 Ählström and Sjöström, CSOs, n 86, 232.

116 Public Eye. 'About Public Eye'. (undated), at: < https://www.publiceye.ch/en/> [last accessed 14 January 2019].

${ }_{117}$ Public Eye. 'Public Eye Awards'. (undated), at: https://www.publiceye.ch/en/campaigns/public-eye-awards/ [last accessed 14 January 2019].
} 
Forthcoming in The Edward Elgar Research Handbook on Human Rights and Business, Surya Deva and David Birchall (eds.) - draft, please do not cite without permission.

\subsubsection{Think-tanks, research and advocacy groups}

The line between watchdog activism and informative research and campaigning is naturally a blurred one. Nonetheless, within BHR there are many CSOs that prioritize neutral and balanced research, including rights to reply and analyses from a broad political spectrum. These groups generally benefit from more legitimate public profiles, making them an authoritative public voice on corporate accountability issues. Among the tools of these broader-based CSOs are public education, research into specific issues, norm diffusion and norm entrepreneurialism, academic and policy influence, and the ability to launch large-scale campaigns.

The Business and Human Rights Resource Centre (BHRRC) keeps up with all relevant legal cases, news stories and policy-making, while also providing a platform for discussion and collating disparate online sources. ${ }^{118}$ Many CSOs investigate corporate activity, fulfilling a function that is part journalism, part academia, and part activism. The Centre for Research on Multinational Corporations (SOMO by its Dutch acronym) describes itself as 'a critical, independent, not-for-profit knowledge centre on multinationals'. Within this remit corporate accountability for human rights violations is often central. ${ }^{119}$ FAFO, a Norwegian organization, fulfil a similar research function. ${ }^{120}$

The International Commission of Jurists promotes respect for international human rights standards, and conducts research to this end. While it would not paradigmatically be seen as an activist group - being composed of ' 60 eminent judges and lawyers' ${ }^{121}$ and with consultative status at the UN - its involvement in the Treaty Alliance lays down a normative marker, showing not just the professionalization of civil society, but perhaps the activistization of professionals. ${ }^{122}$ Others include the largest research and advocacy organizations, such as Amnesty International and Human Rights Watch, and groups such as Greenpeace and Oxfam International. The Institute for Human Rights and Business (IHRB) ${ }^{123}$ and the International Corporate Accountability Roundtable (ICAR) ${ }^{124}$ work specifically on corporate accountability-related issues.

\footnotetext{
${ }^{118}$ Business and Human Rights Resource Centre. 'Homepage' (undated), at: <https://businesshumanrights.org/en> [last accessed 14 January 2019].

${ }^{119}$ See e.g. SOMO, 'Branded Childhood' (2017).

${ }^{120}$ See e.g. Anita Ramasastry and Robert C. Thompson, 'Commerce, Crime and Conflict. Legal Remedies for Private Sector Liability for Grave Breaches of International Law' Oslo: Fafo Institute of Applied International Studies (2006).

${ }^{121}$ International Commission of Jurists. 'About' (undated) at: https://www.icj.org/about/ [last accessed 14 January 2019].

${ }^{122}$ International Commission of Jurists. 'Transnational Corporation Working Group: Joint UN Statement' 10 March 2017, at: 〈https://www.icj.org/transnational-corporation-working-group-joint-un-statement/> [last accessed 14 January 2019].

${ }^{123}$ Institute for Human Rights and Business. 'Home Governments Series - The Role of Capital Markets' 22 March 2017, at:

<https://www.ihrb.org/focus-areas/commodities/home-governments-series-the-role-of-capital-markets > [last accessed 14 January 2019].

${ }^{124}$ International Corporate Accountability Roundtable. 'Public Procurement and Human Rights: A Survey of Twenty Jurisdictions'. April 26 2017, at: <https://www.icar.ngo/publications/2017/4/26/public-procurement-and-human-rights-a-survey-of-twentyjurisdictions $>$ [last accessed 14 January 2019].
} 
Forthcoming in The Edward Elgar Research Handbook on Human Rights and Business, Surya Deva and David Birchall (eds.) - draft, please do not cite without permission.

\subsubsection{Reputational Risk and Consumer Activism}

Reputational risk and consumer activism attempts to inform the public about the ethical performance of brands and to use the consumer power to promote ethical standards. The onus may be on environmental, labour, human rights standards or political change, such as the 'boycott, divestment and sanctions' movement aimed at 'companies profiting from Israel's crimes'. ${ }^{125}$ The fair trade movement uses reputational risk to leverage big consumer brands toward ethical standards. ${ }^{126}$

Changing consumer habits has proven more difficult than many CSOs originally assumed, with information on ethical performance rarely influencing behaviour ${ }^{127}$ (unless a particularly egregious issue rose to prominence). However, new communication tools have encouraged new counter-movements and investigative tactics. Oxfam's Behind the Brands tracks the ethical performance of the top ten global food producers on a variety of metrics, focused on human rights alignment with the UNGPs. Within a year it had attracted the support of investors with US\$1.4 trillion in assets. ${ }^{128}$ At the other end of the scale, CarrotMob organizes flash-mob style 'buycotts' supporting various ethical issues, to create a profit-motivated race to the top. ${ }^{129}$

\subsubsection{Direct Action and Protest}

Peter Utting argues that: 'An influential discourse has emerged which suggests that confrontation, single-issue activism, and criticism that profiles specific problems rather than solutions is 'ideological' or passé and that NGO collaboration with business and engagement with the market is modern and savvy.' 130

This discourse is certainly evident, but may be more relevant to the overtly ideological groups, rather than confrontational, single issue groups. Such groups often form spontaneously as bottom-up protests around the sites of worst atrocity, performed by marginalized front-line groups facing genuine threats to their life in so doing. Direct action is particularly common in land rights and indigenous peoples' rights cases, suggesting that it the most voiceless who resort to these tactics. They inevitably often form in insecure environments, making it a particularly dangerous form of activism. And these movements work. Even in regions where impunity and government complicity appear endemic, the work of individuals such as Berta Caceres and Pavel Sulyandziga has stopped multi-billion dollar

\footnotetext{
${ }^{125}$ BDS Movement, 'What to Boycott', at: $<$ https://bdsmovement.net/get-involved/what-to-boycott $>$ [last accessed 14 January 2019].

${ }^{126}$ Some UK supermarkets are moving away from 'FairTrade' certification and towards their own 'fairly traded' brandings. John Vidal, 'Move by UK supermarkets threatens to bring Fairtrade crashing down' The Guardian 25 June 2017, at: <https://www.theguardian.com/global-development/2017/jun/24/fairtrade-crashing-downsainsburys-tesco-tea-growers-nairobi> [last accessed 14 January 2019].

${ }^{127}$ Felicitas Morhart, Guido Palazzo and Judith Schrempf-Stirling. 'Shopping for a better world: how consumer decisions can help promote sustainability and human rights' in Baumann-Pauly, Dorothée, and Justine

Nolan. Business and Human Rights: From Principles to Practice (Routledge 2016), 201, 201-202.

128 Jochnick and Bickford, Civil Society, n 8, 188.

${ }^{129}$ CarrotMob. 'Campaigns' (undated) <http://www.carrotmob.org/campaigns $>$ [last accessed 14 January 2019].

${ }^{130}$ Utting, Corporate, n 85.
} 
Forthcoming in The Edward Elgar Research Handbook on Human Rights and Business, Surya Deva and David Birchall (eds.) - draft, please do not cite without permission.

projects from going ahead, and raised a level of awareness that would be otherwise unthinkable (see below).

Other forms of direct action are considered passé. This generally includes violence, and more concretely violence in developed states and/or without a very specific goal. When anticorporate black bloc groups rampage through cities, their tactics render them illegitimate to many. Other forms of direct action, including strikes, protests and occupation are also in long-term decline, at least in developed states. ${ }^{131}$ They rely on gaining widespread support, and so mainstream opinions may be self-reinforcing.

\subsubsection{Global coordination and movements}

Alliance building is increasingly important as the number of specialized CSOs grows. This is especially true around the many transnational and international corporate-related human rights. Many of the groups already mentioned act as hubs, and themselves team up to provide normatively forceful pressure over specific issues. One prime example is Treaty Alliance, in support of the binding treaty on business and human rights. They describe themselves as 'An alliance of committed networks and campaign groups around the world... in support of developing a binding international instrument to address human rights abuses committed by transnational corporations and other business enterprises. ${ }^{132}$ The Alliance brings together a highly diverse range of actors, from the global reach of Friends of the Earth, to the legal expertise of the ICJ, right to food campaigners FIAN International, and explicitly anticorporate actors such as TNI.

A further member of the Treaty Alliance is the International Network for Economic, Social and Cultural Rights (ESCR-net) which is itself composed of 'over 280 NGOs, social movements and advocates across more than 75 countries.' 133 The network works on a variety of issues related to Economic, Social and Cultural Rights, including corporate accountability, adopting an eclectic variety of tactics. ${ }^{134}$ The International Federation of Human Rights (FIDH by its French acronym) has over 150 members and facilitates global coordination. ${ }^{135}$

\subsection{Problems Faced by HRDs and CSOs}

HRDs frequently put themselves at risk on the front-line against corporate activity. Most attacks were connected to extractive and energy industries, followed by agribusiness. ${ }^{136}$ Global sustainable development agreements, so the United Nations Special Rapporteur on Human Rights Defenders writes, are 'doomed to fail if those individuals and groups on the frontline of defending sustainable development are not protected at the national, regional and

\footnotetext{
${ }^{131}$ John Godard. 'What has happened to strikes?' (2011) 49.2 British Journal of Industrial Relations 282.

132 Treaty Alliance, n. 97.

${ }^{133}$ ESCR-net. 'Homepage', at: $<$ https://www.escr-net.org/> [last accessed 14 January 2019].

${ }^{134}$ ESCR-net. 'Corporate Accountability', at: $<$ https://www.escr-net.org/corporateaccountability $>$ [last accessed 14 January 2019].

${ }^{135}$ FIDH, at: <https://www.fidh.org/en/> [last accessed 14 January 2019].

${ }^{136}$ A/HRC/71/281 n. 14, para. 27.
} 
Forthcoming in The Edward Elgar Research Handbook on Human Rights and Business, Surya Deva and David Birchall (eds.) - draft, please do not cite without permission.

international levels. ${ }^{137}$ This section uses case studies to exemplify the nature and scale of the problem.

\subsubsection{Pavel Sulyandziga}

Pavel Sulyandziga, a member of the UN Working Group on Business and Human Rights, ${ }^{138}$ has experienced first-hand some of the tactics used against HRDs. He has spent years defending the rights of indigenous peoples' in his homeland in Far East Russia, where largescale logging operations threaten the Northern hemisphere's largest forest, and the way of life of the local people. In 2015 the land became a national park, and indigenous access rights were guaranteed. ${ }^{139} \mathrm{He}$ recently gained asylum in the US.

Sulyandziga and his allies have faced years of serious threats. The wife and child of another indigenous leader were attacked; a friend of his son had his apartment searched by police; police detained for two days an acquaintance who picked him up at an airport; his assistant fled the country after refusing to admit to being an anti-government rebel; his brother has been detained by police previously, and is now avoiding making political statements. ${ }^{140}$ The climate of fear is extended by the number of deaths and disappearances of critics of the government. The politician Boris Nemtsov and a number of journalists have been killed in mysterious circumstances, and fleeing Russia is not necessarily enough.

Another more systemic tactic is to designate CSOs as 'foreign agents'. Sulyandziga's International Development Fund for Indigenous Peoples of the North, Siberia and the Far East of the Russian Federation, also called the Batani Fund, was added to the list in March 2016. Since its designation as a foreign agent, the Batani Fund has become inactive. ${ }^{141}$

Under the 2012 law, groups must register with the Justice Ministry as 'foreign agents' if they receive any funding from any foreign sources, governmental or private, and engage in 'political activity'. ${ }^{142}$ In May 2016, parliament adopted another set of amendments to the law, expanding the controversial definition of 'political activity' to include, among other things, any attempt by an independent group to influence public policy, regardless of the group's mandate. In Russia, as elsewhere with similar rules, there is a strong normative connotation that goes with the term 'foreign agent'. 'The foreign agents law was designed to shackle, stigmatise, and ultimately silence critical NGOs,' says Sergei Nikitin, Director of Amnesty International Russia. ${ }^{143}$

\footnotetext{
137 ibid. para 94.

${ }^{138}$ Human rights and transnational corporations and other business enterprises UN Doc A/HRC/RES/17/4

${ }^{139}$ Megan Doyle. 'Maine's a haven for asylum seeker from Russia' Portland Press Herald 17 April 2017. At: <http://www.pressherald.com/2017/04/16/maines-a-haven-for-asylum-seeker-from-russia/> [last accessed 14 January 2019] ('Doyle, Haven').

140 ibid., and: Thomas Nilsen. 'Indigenous Peoples activist detained in Moscow' The Barents' Observer 11 December 2016, at: <https://thebarentsobserver.com/en/2016/12/indigenous-peoples-activist-detained$\underline{\text { moscow }>~[l a s t ~ a c c e s s e d ~} 14$ January 2019].

${ }^{141}$ Doyle, Haven, n. 139

${ }^{142}$ HRW. 'Russia: Government vs. Rights Groups' 1 June 2017, at:

<https://www.hrw.org/russia-government-against-rights-groups-battle-chronicle> [last accessed 14 January 2019].

${ }^{143}$ Amnesty. 'Russia: Four years of Putin's 'Foreign Agents' law to shackle and silence NGOs' 18 November 2016, at:
} 
Forthcoming in The Edward Elgar Research Handbook on Human Rights and Business, Surya Deva and David Birchall (eds.) - draft, please do not cite without permission.

\subsubsection{Berta Cáceres}

Another indigenous rights activist, Berta Cáceres was killed by gunmen in her home in La Esperanza, Honduras on the $3^{\text {rd }}$ of March 2016. ${ }^{144}$ In 1993, she cofounded the National Council of Popular and Indigenous Organizations of Honduras (COPINH) to address the growing threats posed to indigenous communities, to fight for their territorial rights and improve their livelihoods. The murder was linked to her role as an activist challenging corporate activity in mining, power production, and particularly the Agua Zarca dam, run by a corporation known as Desa. ${ }^{145}$ In November 2018 seven people were convicted of the murder by a Honduran court. ${ }^{146}$ These included the Desa communities and environment manager and the former Desa security chief, alongside several ex-Honduran military personnel. ${ }^{147}$ Cáceres's family believe the masterminds are still at large. ${ }^{148}$

Honduras' suffers from a culture of violence and impunity. 'Honduras is the world's most dangerous country per capita to be an environmental or land defender, with at least 109 people killed between 2010 and 2015. ${ }^{149}$ Tomas Garcia, a community leader from Rio Blanco, was shot and killed during a peaceful protest at the dam office. Others have been attacked with machetes, discredited, detained, and tortured. '[O]ver $90 \%$ of killings and abuses against Honduran human rights defenders reportedly remain unsolved. ${ }^{150}$ However, things may gradually improve if, as the case suggests, the culture of impunity gradually recedes. There is also developing international pressure. The Berta Cáceres Human Rights in Honduras Act proposes to suspend U.S. funding to the Republic of Honduras for their police and military operations, until the Honduran government investigates the role of police and military in human rights violations. ${ }^{151}$

\subsubsection{Legal and Governmental Tactics Against HRDs and CSOs}

Corporations and governments are increasingly using the legal system against CSOs and HRDs. 'Globally, of the 450 cases of violence, threats and harassment in 2015-16 included in

<https://www.amnesty.org/en/latest/news/2016/11/russia-four-years-of-putins-foreign-agents-law-to-shackleand-silence-ngos/> [last accessed 14 January 2019].

${ }^{144}$ Goldman Prize. 'Berta Cáceres'. (undated), at: <http://www.goldmanprize.org/recipient/berta-caceres/> [last accessed 14 January 2019].

${ }^{145}$ Johnathan Watts. 'Berta Cáceres, Honduran human rights and environment activist, murdered' The

Guardian. 4 March 2016, at:

<https://www.theguardian.com/world/2016/mar/03/honduras-berta-caceres-murder-enivronment-activisthuman-rights $>$ [last accessed 14 January 2019].

${ }^{146}$ Nina Lakhani. 'Berta Cáceres court papers show murder suspects' links to US-trained elite troops'. The Guardian. 21 February 2017, at:

$<$ https://www.theguardian.com/world/2017/feb/28/berta-caceres-honduras-military-intelligence-us-trainedspecial-forces> [last accessed 14 January 2019].

${ }^{147}$ https://www.theguardian.com/world/2018/nov/29/berta-caceres-seven-men-convicted-conspiracy-murderhonduras [last accessed 14 January 2019].

${ }^{148}$ https://www.theguardian.com/world/2018/nov/30/berta-caceres-case-a-warning-shot-for-those-who-wouldkill-activists [last accessed 14 January 2019].

${ }_{149} \mathrm{~A} / \mathrm{HRC} / 71 / 281$, n. 14, para 36.

${ }^{150} \mathrm{BHRRC}$, 'Corporate impunity is common \& remedy for victims is rare' Corporate Legal Accountability Annual Briefing (2017) 3 (BHRRC, Impunity) at: $<$ https://businesshumanrights.org/sites/default/files/documents/CLA_AB Final_Apr\%202017.pdf> [last accessed 14 January 2019]

${ }^{151}$ H.R.5474 - Berta Caceres Human Rights in Honduras Act 
Forthcoming in The Edward Elgar Research Handbook on Human Rights and Business, Surya Deva and David Birchall (eds.) - draft, please do not cite without permission.

[BHRRC's] Human Rights Defenders Database, 166 involved criminalisation and legal harassment of activists and their actions, including 64 cases of lawsuits against them and 75 cases of arbitrary detention. ${ }^{152}$

Corporations can use a number of delaying tactics in court to drain activists of funding and motivation, while cross-border cases add barriers and complexity. ${ }^{153}$ Andy Hall, an activist studying labour rights in Thailand has been convicted under their criminal defamation laws. ${ }^{154}$ Activists have faced lawsuits for Twitter postings ${ }^{155}$ and for launching legal actions. ${ }^{156}$ Locals protesting a coal ash landfill in an economically deprived area of Alabama are facing a $\$ 30$ million defamation claim. ${ }^{157}$ This is an example of a strategic lawsuit against public participation (SLAPPs). 'SLAPPs are often filed by companies to intimidate and silence people seeking to participate in matters of public interest, burdening them with legal costs until they abandon their criticism or opposition - and can thus bar victims from accessing justice. ${ }^{158}$ SLAPPs are often not intended to be successful claims, but rather are designed to silence HRDs by tying them up in costly litigation processes. Some US states and Canadian provinces have legislated protections against SLAPPs. ${ }^{159}$

A common state tactic, particularly in authoritarian states, is to label HRDs as unpatriotic, vandals, saboteurs, even terrorists, so that they become delegitimized in the eyes of the public. ${ }^{160}$ This is one purpose of the foreign agent designation in Russia. China recently enacted a similar rule. Foreign NGOs must register with the government and 'must not endanger China's national unity, security, or ethnic unity; and must not harm China's national interests, societal public interest'. ${ }^{161}$ One UN report discussed the growing trend towards criminalization of HRDs work, supported by a public discourse that the HRDs were 'opposed to development'. ${ }^{162}$ One major overarching problem is the ever-increasing transnationalism of corporate activity, which is not matched by statist jurisdictions. A corporation can operate in states unable or unwilling to prosecute human rights violations, yet victims often have minimal prospects of accessing the corporation's home state legal system. Until this changes, state actions against HRDs are likely to be effective.

\footnotetext{
${ }^{152}$ Elodie Aba and Ciara Dowd. 'Why it's getting harder (and more dangerous) to hold companies accountable' OpenDemocracy 21 May 2017, at: <https://www.opendemocracy.net/openglobalrights/ciara-dowd-elodie-aba/why-it-s-getting-harder-and-moredangerous-to-hold-companies- [last accessed 14 January 2019].

${ }^{153}$ HRC. 'Improving accountability and access to remedy for victims of business-related human rights abuse' A/HRC/32/19, para. 24.

${ }^{154}$ BHRRC, Impunity, n 1504.

155 Ibid 5.

156 Ibid 5.

${ }^{157}$ ACLU. 'ACLU makes free speech case defending residents of low-income, majority black Alabama town' 2 June 2016, at: <https://www.aclu.org/news/environmental-protesters-fight-defamation-lawsuit-filed-coal-ashlandfill> [last accessed 14 January 2019].

${ }^{158}$ BHRRC, Impunity, n 1508.

159 ibid

${ }^{160}$ Jacqueline Wood, 'Unintended consequences: DAC governments and shrinking civil society space in Kenya' (2016) 26.5 Development in Practice 532.

${ }^{161}$ China File, 'China's Foreign NGO Law', http://www.chinafile.com/ngo/latest/fact-sheet-chinas-foreign-ngolaw [last accessed 14 January 2019].

${ }^{162}$ Report of the Special Rapporteur on the situation of human rights defenders, A/68/262, August 2013, para. 15 .
} 
Forthcoming in The Edward Elgar Research Handbook on Human Rights and Business, Surya Deva and David Birchall (eds.) - draft, please do not cite without permission.

\subsection{The Business Role in Protecting CSOs and HRDs}

Businesses operating in rights-restrictive environments are in a strong position to pressure governments, particularly if gross human rights violations are being committed, while home state governments are similarly able to pressure firms. ${ }^{163}$ The investment, tax revenue and numerous other benefits which business - particularly large transnational business - brings to a state, combined with the ability of capital to move globally, means that states are forced to listen. ${ }^{164}$

There are ethical, business case, and legal rationales as to why businesses should work to protect HRDs and CSOs. A business that even pays lip service to the idea of human rights would appear to be under an ethical obligation to protect HRDs where reasonably possible. ${ }^{165}$ Many business case logics were implied in the preceding section, such as shareholder activism and critical reports. Legal challenges are also increasingly likely. This includes the public pressure that pushes courts such as in Honduras to address domestic crimes, and the growing trend towards extraterritorial jurisdiction (see Chapter 12), a trend that would be significantly increased if the proposed binding treaty comes to fruition.

There is also the looming possibility of complicity in human rights abuse. This may be direct complicity, requiring intentional participation and for which criminal liability may be possible, ${ }^{166}$ or indirect or beneficial complicity, which can occur from facilitating or gaining benefits from a human rights abuse. ${ }^{167}$ Silent complicity requires only a 'passive stance toward the violation of human rights'. ${ }^{168}$ The UNGPs notion of 'nonlegal' complicity is important as regards the business case to protect HRDs. 'As a nonlegal matter, business enterprises may be perceived as being "complicit" in the acts of another party where, for example, they are seen to benefit from an abuse committed by that party.' 169 The guidance notes 'that public opinion sets the bar lower [than the legal system] and can inflict significant costs on [corporations]. ${ }^{, 170}$ Corporations perceived to be either benefitting from, or silent in the face of, human rights violations against HRDs and CSOs may be risking serious social repercussions.

The leverage of the corporation is crucial in determining whether it can act meaningfully against a state. As Wettstein says, 'for a corporation to have a positive duty to address human

\footnotetext{
${ }^{163}$ See on the reflexive business-state pressure in the context of Burma: John G. Dale Free Burma: transnational legal action and corporate accountability (U of Minnesota Press 2011).

${ }^{164}$ David Vogel, 'Socially Responsible Lobbying.' Harvard Business Review, 86(2), (2008) 41; Florian Wettstein, and Dorothea Baur, 'Why Should We Care about Marriage Equality?'; Political Advocacy as a Part of Corporate Responsibility' 138.2 (2016) Journal of Business Ethics, 199.

${ }^{165}$ See e.g. Wesley Cragg, 'Ethics, enlightened self-interest, and the corporate responsibility to respect human rights: A critical look at the justificatory foundations of the UN framework' Business Ethics Quarterly 22.1 (2012) 9 and for a full account: Wettstein, Global Justice (n 2).

166 Guiding Principles, n 37 Principle 17 (commentary)

${ }^{167}$ Andrew Clapham and Scott Jerbi, 'Categories of corporate complicity in human rights abuses' (2000)

24 Hastings International and Comparative Law Review 339.

${ }^{168}$ Florian Wettstein, 'Silence as complicity: elements of a corporate duty to speak out against the violation of human rights. In Wesley Cragg, ed. Business and Human Rights. (Edward Elgar 2012) 108. (hereinafter

'Wettstein, Complicity')

169 Guiding Principles, n 37 Principle 17 (commentary)

${ }^{170}$ OHCHR, 'The Corporate Responsibility to Respect Human Rights: An Interpretative Guide' (2012), 5
} 
rights violations... its opposition... must matter to the actual or potential perpetrator'. ${ }^{171} \mathrm{~A}$ small corporation with a Moscow office is unlikely to change the Russian state's actions. Conversely, in the much studied Shell in Nigeria case, clear links between Shell and state repression are evident and Shell at the time produced around half of Nigeria's crude oil. 'Shell's power and influence was by any means considerable'. ${ }^{172}$ Thus, Shell's silence in the face of Nigerian government violence towards demonstrators may be seen as facilitating, or at least failing to prevent, egregious human rights violations. Silence, as Wettstein states, 'is not always neutral'. ${ }^{173}$ Sometimes merely voicing an objection can put pressure on a state. The reaction of many firms to Donald Trump's decision on the Paris Climate Accord showed at least the discursive power of business speaking out. ${ }^{174}$ By speaking with one voice on these issues, firms can pressure governments through their financial power into treating CSOs and HRDs with dignity.

\subsection{The Business-Society Landscape}

The surge in CSO engagement in recent years has seen new gains, new opportunities, and new issues, not least of which is the growing threats to HRDs. CSOs are adopting new tactics of both confrontation and collaboration, conducting research and increasingly setting the BHR agenda. CSOs are able to address issues beyond the scope of governments, to shine a light on marginalized groups around the world, and contest corporate power in ways in which states are all-too-often unwilling. CSOs are an increasingly influential voice in global policymaking, as well as policymakers themselves. The growing proactivity of CSOs and HRDs has marked them out as threats to the state. Governments have obligations to protect HRDs within their borders, and increasingly extraterritorially. Corporations have a responsibility to respect human rights, including by avoiding all forms of complicity in human rights violations. It is difficult to reconcile the culture - described above - of silence, resistance, strategic lawsuits and legal obfuscation with this responsibility. Despite the problems there exists an evident trend towards greater responsibility, which, while often implemented by corporations themselves or imposed by law, frequently has its roots in civil society activism and idealism. Doing more to protect and facilitate civil society is one necessity of the BHR movement.

\footnotetext{
${ }^{171}$ Wettstein, Complicity, n 168, 120

172 ibid, 122

173 ibid, 124.

${ }^{174}$ Daniel Victor, 'Climate Change Is Real': Many U.S. Companies Lament Paris Accord Exit' New York Times 1 June 2017, at: <https://www.nytimes.com/2017/06/01/business/climate-change-tesla-corporations-parisaccord.html $>$ [last accessed 14 January 2019].
} 